\title{
Enhancing consumer online engagement through consumer involvement: A case of airline and hospitality services in Malaysia
}

\author{
Mei Kei Leong ${ }^{a}$, Syuhaily Osman ${ }^{\text {}}$, Laily Paim ${ }^{b}$ and Sabri Mohamad Fazlib
}

${ }^{a}$ School of Hospitality, Selangor Darul Ehsan, Sunway University, Malaysia

${ }^{b}$ Department of Resource Management and Consumer Science, Selangor Darul Ehsan, Universiti Putra Malaysia, Malaysia

\section{H R O N I C L E}

\section{Article history:}

Received: December 2, 2018

Received in revised format: March

3, 2019

Accepted: March 8, 2019

Available online:

March 8, 2019

Keywords:

Consumer involvement

Consumer online engagement

Airline and hospitality services

\section{A B S T R A C T}

\begin{abstract}
Consumer online engagement has seen a sight of emerging attention by marketing literature, but how consumer involvement, with its dimensions (importance, pleasure, sign, risk consequence, and risk probability), is linked with consumer online engagement still requires additional empirical analysis especially in the context of airline and hospitality services. The purpose of this study is to examine the relationship between consumer involvement and its dimensions and consumer online engagement. The data are collected from the social media website and analyzed by using structural equation modelling through SPSS and Smart PLS 3.0 software. The findings imply that sign value was the major determinant of consumer online engagement. This indicates that marketers should acknowledge the importance of company's symbolic value and design a suitable symbolic value to be parallel with the targeted consumers' social status and personal images to increase consumer online engagement. Through examining the relationship among different variables, marketers could develop effective strategies to gain competitive advantages. The originality of this study lies within the research gap of the past researches on the antecedent of consumer online engagement. The antecedent considered is consumer involvement, suggested by previous researches.
\end{abstract}

\section{Introduction}

Service sector has become increasingly important and it is a major job creator across the countries. Among the services provided, the major growing services are the airline and hospitality services in the tourism industry. These service sectors have been increasingly creating jobs, providing trade practices, drives export, increasing capital investment and entrepreneurships (Turner, 2018). According to Smith (2004), the airline and hotel services are interlinked with each other, as the modern hotel industry sees the significant growth rate along with air travel. Airline and hospitality services have seen dramatic increase in sales and they are essential for economic development. In the global level, the airline and hospitality services have gained a total of 1229.76 billion US dollar revenue in 2017 (The Statistical Portal). Even in Malaysia, airline and hospitality services have contributed approximately RM65 billion to gross domestic products (GDP) (Turner, 2018a). The large amount of contributions made by the services has

* Corresponding author

E-mail address: maggiel@sunway.edu.my (M. K. Leong) 
increased the marketers' interest to invest in airline and hotel sectors continuously to improve the service quality and perceived value for guests (Kapiki, 2012).

Airline companies in Malaysia have seen an increase competition on many aspects even though this sector is an oligopoly market. With the emerging of internet and the impact of globalization, the international airline market in recent years have caused intense competition (Ion, 2011). International flight companies have enabled ease of purchase for the consumers and ultimately increased the availability of the choices. The main criteria for Malaysian in choosing airline is mainly due to the value for money and safety (Oyewole et al., 2008; Sukati et al., 2015). However, low quality of services offered such as flight delays, in flight experience, customer services and uncomfortable plane seats have caused consumers to have negative perception (Amiruddin, 2013). In addition, the recent strengthened policy enforcement of limiting 7 kilograms of hand luggage for every customer has had a negative impact on customers. Therefore, retaining customers is getting difficult due to the issue presented.

According to the Malaysian Association of Hotel (2015), the number of hotels in Malaysia increased from 1492 to 2628 hotels over the period 2000-2014. There is a difference of 1136 hotels in 14 years, which implies a huge development of hotel industry in Malaysia. The increasing number of hotels has intensified the competition among the marketers. As the supply for the hotels has increased, the demand for the consumers towards the hotel quality has increased too (Nasution \& Mavondo, 2005). However, good services provided for the consumers are no longer sufficient to retain the consumers. Enhanced services in relationship such as build bonding and stay connected with the consumers have become prudent element.

One of the ways of bonding is to stay connected through social media. As the world is turning into a technological era, the consumers are also spending more time on the social media than before. In 2017, a total of 21 million people in Malaysia were accessed to the internet and 19 million of them were social media users (Internet World Stats). The most well-known types of social media are Facebook and Twitter (Sawyer, 2011). By using online social media, customer engagement can be built (Cabiddu et al., 2014) as customer engagement can be built through two different environments. According to Greve (2014), offline engagement is a one-way communication such as distributing brochures and spreading word of mouth while offline engagement is a two way communications. Consumers are able to provide feedback to the company and gain mutual understanding. Besides, cultivating consumer online engagement will eventually affect the long term relationship between the company and consumers. Consumer engagement has been discovered to be able to influence trust, loyalty, and brand evaluation in tourism context (So et al., 2014).

Preserving the connection and increase the involvement with the consumers will eventually lead to engagement with the service company (Bowden, 2009). However, the influencing factors of consumer online engagement is insufficiently investigated. Previous studies investigated customer engagement as the co-creation process to influence customers and company values (Kunz et al., 2017). Some researchers used customer engagement as an independent variable to influence commitment, satisfaction (Wirtz et al., 2013), loyalty (So et al., 2016), and subversion (e.g. Harwood \& Garry, 2015). However, little attention is devoted to examine the consumer online engagement in consumer involvement perspectives. Furthermore, Floreddu and Cabiddu (2016) suggested that elements that affect customer engagement may require in depth studies to have a more comprehensive understanding.

Besides, consumer involvement has been used as uni-dimensional concept (Vivek et al., 2012; Altschwager et al., 2014; Hollebeek et al., 2014) and only a few of them have used multi-dimensional construct on consumer involvement (Kim, 2005; Liang, 2012; Celuch et al., 2014). Kapferer and Laurent (1985) stated that consumer involvement is a complex construct and single dimension is unable to represent consumer involvement comprehensively. Thus, this research uses multi-dimension as the construct for consumer involvement. Among all the proposed dimensions, consumer involvement profile's constructs were used in this research. The constructs might be able to represent consumer involvement with 
a huge coverage. Consumer involvement dimensions includes importance, pleasure, sign, risk consequence, and risk probability. These dimensions are usually examined for product category (e.g. O'cass \& Fenech, 2003; Kim, 2005; Rahbarian \& Meshkani, 2013). Nonetheless, these dimensions were also compatible and have used for service sector (e.g. Chen et al., 2008).

This research aims to examine the relationship between consumer involvement and consumer online engagement in airline and hospitality services. The focus of study was in Malaysia because of the decreasing share price of airline (IATA Economics, 2018) and increasing competitiveness of hotels sectors in Malaysia (Syaqirah \& Faizurrahman, 2014). Through building consumer online engagement in this technological era, it has become possible to increase the competitive advantage and enhance customercompany relationship (Fernandes \& Esteves, 2016). Hence, investigating the relationship between consumer involvement and consumer online engagement in multi-dimensions is essential in airline and hospitality services in Malaysia.

\section{Literature review}

\subsection{Consumer involvement}

Consumer involvement is important to understand the consumers' attitude towards a certain product or services as well as to increase the level of interest (Guthrie \& Kim, 2009). Involved consumers would develop more interest to the product or services due to the participation and eventually engaged with the company that goes beyond the purchase transaction (Żyminkowska et al., 2017). Consumer involvement is defined as the degree of importance of an object to an individual or an individuals' ego structure.

Consumer involvement has been widely studied in multiple research area. However, the dimension of consumer involvement is still inconsistent. According to Laurent and Kapferer (1985), consumer involvement is a complicated variable and thus uni-dimensional variable is unable to measure the variable, extensively. Hence, this research applies a multi-dimensional consumer involvement as recommended by Laurent and Kapferer (1985). Consumer involvement is comprising of importance, pleasure, sign, risk consequence, and risk probability as the dimension (Laurent \& Kapferer, 1985). Consumer involvement is the antecedent of consumer engagement (Hollebeek et al., 2014), this is because the consumers' level of involvement will stimulate consumer engagement. This has been proven in several contexts including social context (Zhang et al., 2011), marketing context (Vivek et al., 2012), and tourism context (Harrigan, et al., 2017). In a research done by Vivek et al. (2012), consumer involvement and consumer engagement maintained a significant relationship with each other. Consumers who are actively involved in the services have found to be more engaged with the company (Leckie et al., 2016) in tourism context (So et al., 2014). Hence, this study proposes the following hypothesis:

$\mathrm{H}_{1}$ : Positive consumer involvement increases the consumer online engagement in airline and hospitality services.

Importance in consumer involvement is referred to as the perceived importance of the product (Laurent and Kapferer, 1985). It indicates whether a particular product or services is compatible with an individual goal. In addition, importance dimension is often associated with interest dimension as it refers to the level of personal interest and meaning that the product carries for an individual (Vazifehdoost \& Kia, 2015). In a learning task design context, Chen and Darst (2001) revealed that high situation interest will precipitate the level of engagement rather than a low situation interest. In consumerism context, Chalil and Dharmmesta (2015) found out that highly involved consumers would find the products or services to be compatible with their hobby and eventually search for more information. Through the searching process, consumers tend to be more exposed and involved with the airline and hospitality services. By continuously exposing to the services, the likelihood of getting engaged with the company will be increased. Thus, this research believes that positive importance of consumer involvement would influence the engagement of the consumer positively. The following hypothesis is proposed: 
$\mathrm{H}_{2}$ : Positive importance increases the online engagement of consumers in airline and hospitality services.

Pleasure explains the hedonic value caused the enjoyment feeling given by the products or services to an individual (Laurent \& Kapferer, 1985). Pleasure is often associated with the emotional values (Jung \& Jin, 2016). In a context of conspicuous consumption of luxury brands, hedonic value can be attained by possession of the product (Truong, 2010). Pleasure value can be felt by the consumers through the services offered by the airline or hotels. Consumers enjoy the inflight service environment provided by the airline company such as the seats, music, foods, spaces and personal television. Those services will influence consumers' pleasurable value (Chen et al., 2008). When a product or services provided the emotional appeal of pleasure value to the consumer, consumer would tend to have favourable feeling to the company (Chaudhuri \& Holbrook, 2001) and eventually consumer will be engaged with the company. Parker and Wang (2016) also investigated that engagement is the main reason for consumers to feel relaxed and has motivated the hedonic value. Thus, pleasure value will positively influence consumer engagement. The proposed hypothesis is as follow:

$\mathrm{H}_{3}$ : Positive pleasure increases the consumer online engagement in airline and hospitality services.

Sign is the key component of the company to influence consumer loyalty. It has a unique symbolic value perceived by an individual of a product or services (Laurent \& Kapfere, 1985). The symbolic value perceived by the consumer is usually associated with the individual social status, personality, and identity (Chalil \& Dharmmesta, 2015). For instance, luxury hotels are always perceived as a high social class by consumers and they are able to gain prestige value from staying in the hotel. Firat et al. (2013) found out that the symbolic value of a product or services is able to influence consumer's consumption behaviour. $\mathrm{Li}$ and Sun (2015) also discovered that the symbolic value is very essential in determining the decision making of consumers to become loyal consumers. This view is also proven by Thongthip and Jaroenwanit (2016) found that emotional value perceived by the consumers is closely associated with brand engagement. They believed that consumers are associated with the airline and hospitality services through their images, personality or social status. Therefore, this research proposed the following hypothesis:

$\mathrm{H}_{4}$ : Positive sign increases the consumer online engagement in airline and hospitality services.

The concept of risk is vital in scientific researches but there is no unified definition or interpretation. One of the risk's definitions proposed by Lawrance (1976) is the measure of possibility unwanted repercussion. Masoud (2013) observed that risk is essential in influencing the consumers' behavior with great contribution on consumer decision making process. Risk is often associated with perceived risk and there were two types of perceived risk proposed by Laurent and Kapferer (1985) which were risk consequence and risk probability.

Risk consequence is different with risk probability. There is a thin layer of distinction between risk consequence and risk probability. Risk probability is a consumer's consideration before purchasing the services while risk consequence is a consideration after purchase such as the negative consequence may face by the consumer. Risk consequence is an individual perceived importance of the possibility negative consequence through the wrong choices made towards a certain product (Laurent \& Kapferer, 1985). However, having high risk consequence is not a good sign for building consumer online engagement. This mostly because risk consequence is a negative thinking towards the product or services that the choices they made might have negative consequence. In addition, consumers having risk consequence also proved of not trusting a product or service the company offered (Mukherjee \& Nath, 2007). Without believing the airline and hospitality services, it is very difficult to build consumer online engagement. Lee et al. (2016) also stated that the uncertainty of having risk may cause diffusion and negative impact towards the brand relationship. Hence, the hypothesis derived is as follows:

$\mathrm{H}_{5}$ : Lower risk consequence increases the consumer online engagement in airline and hospitality services. 
Risk probability represents the degree of consumer perceived mis-purchase (Quester \& Lin Lim, 2003). The uncertainty of purchasing a product or services is often associated with the risk probability prior to making purchase decision. Risk probability usually occurs for consumers at the stage of consideration before the purchasing occurs. The risk probability perceived by consumers are including of financial risk, social risk, physical risk and technological risk (Gerber et al., 2014). In this research, financial risk is closely related to the context of airline and hospitality services. Consumers would consider the financial risk which is the cost incurred when booking the flight ticket especially from the low cost airliners (Lerrthaitrakul \& Panjakajornsak, 2014). They are uncertain if the price would increase or decrease in near future as the prices of the flight tickets are unstable due to promotions and yield management (Donovan, 2005). Therefore, consumers may perceive a certain degree level of risk probability prior to making a purchase.

However, perceived risk probability is a negative assumption towards the airline or hospitality services company. Consumers perceived that they might purchase the mistaken and unsuitable product for them (Laurent \& Kapferer, 1985). According to Hu (2012), consumers will avoid risky purchasing decision for unfamiliar product or service. In addition, services will increase the perceived risk of the consumers due to the intangibility of services offered (Cases, 2002) especially in airline and hotel services. This shows that the higher perceived risk probability by the consumer, the lower the sense of engagement to the services. Thus, this study derived the following hypothesis:

$\mathrm{H}_{6}$ : Lower risk probability increases the consumer online engagement in airline and hospitality services.

\subsection{Consumer online engagement}

Consumer engagement is an emerging term in marketing academic research after 2005 (Brodie et al., 2013). Attention given to the marketing literatures are increasing in social media (Farook \& Abeysekara, 2016; Roux \& Maree, 2016), tourism (So et al., 2016), branding (Brodie et al., 2013; Greve, 2013; Apenes Solem, 2016), and mobile application context (Dovaliene et al., 2016). However, consumer engagement is still in its infancy stage of research.

During the past 6 years, the number of active social media users increased from 1.4 billion users worldwide in 2012 to 2.62 billion users in 2018 (Statista, 2018). It has shown a significant increment in the number of social media users. According to Wirtz and Gottel (2016), social media has become an important platform to stay connected with family, friends, colleagues and customers. Moreover, with the advancement of social media website, the consumers are allowed to participate in the activity held by the airline or hotel companies. Bonding between the consumers and company could be easily connected through the social media (Guha et al., 2018). Staying connected with consumers through social media has been practiced worldwide by many organizations such as Airasia, Malaysia Airlines, Marriot Hotel and Cathay Pacific by having their own Facebook or Twitter page. Through social media such as Facebook and Twitter, companies are able to create campaign, posts recent promotions upload tempting photographs of services and even broadcast live video (Ohajionu \& Mathews, 2015).

Associate with that, this research has focused on consumer online engagement. In this paper consumer online engagement is referred to a degree of affective, behavior and cognitive attachment of an individual to a certain services or company through online social media. Consumer online engagement is an essential element to be studied in recent marketing literature. According to Bowden (2009), engaged consumers will subsequently build loyalty towards some certain brand. This indicates that cultivation of consumer loyalty will be easier if the consumers are attached or engaged with the services or company especially through the social media engagement.

Meanwhile, the inconsistency of the different dimensions proposed by researchers are present. Van Doorn et al. (2010) claimed that consumer engagement is a uni-dimensional construct while others believe that consumer engagement is a multi-dimensional construct (Vivek et al., 2012; Hollebeek et al., 2014). In a previous paper focuses on social media context, Dessart et al. (2015) recommended that future 
researchers may establish a comprehensive consumer engagement dimension to stabilize the dimension. Hence, the dimensions of consumer online engagement in this research are inclusive of affective engagement, behavior engagement and cognitive engagement to enable a broader understanding.

\subsection{Conceptual framework}

The conceptual framework elucidates consumer involvement and its dimensions (importance, pleasure, sign, risk consequence, and risk probability) influences consumer online engagement in airline and hospitality services. The proposed conceptual framework is presented int Fig. 1.

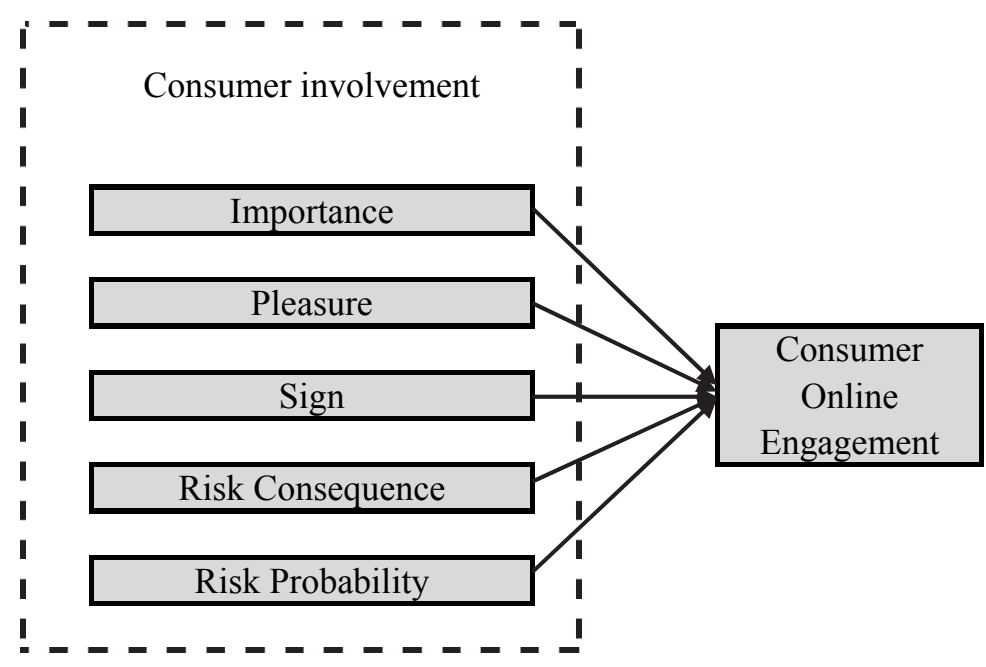

Fig. 1. Proposed conceptual framework

\section{Methodology}

This is an applied study with quantitative method which distributes self-administered questionnaire through online software. There are three sections in the questionnaire distributed. The first section of the questionnaire is associated with the demographic background of the respondents. The following section measures the consumer involvement and is adapted from Laurent and Kapferer (1985) which contains of 15 questions. The dimensions of consumer involvement are inclusive of importance, pleasure, sign, risk consequence, and risk probability. The final section of the questionnaire contains 21 items to measure consumer online engagement variable adapted from Cheung et al. (2011). Both of the sections namely consumer involvement variable and consumer online engagement ranged choices from 1- strongly disagree to 5- strongly agree.

The target population of this study consists of active users of social media and possess purchase power. They also should have some experiences in purchasing airline tickets or booking hotel rooms prior to this study. Having past experience is important because the consumers have felt the services before and may have further understanding towards the service provided. The samples were collected through Facebook because it has the highest number of active social media users (Statista, 2018a). The study used cross sectional research design to collect the data from respondents only once. The data were gathered by using convenience sampling due to the unavailability of accurate number of population for social media users and consumers who have experiences in purchasing the services. Prior to the actual data collection, a pretest was conducted to ensure the respondents understand the wording and meaning of the questionnaire. A total of 30 responses were collected from the pre-test and the results show that the questions were understandable. For the actual data collection, this research used a calculation equation to compute the ideal sample size of the respondents for unknown population. According to Smith (2013), it is appropriate to use equation calculation method to calculate the sample size for the unknown population. A total of 390 respondents completed the questionnaire. 


\section{Data analysis}

The data collected was keyed-in by using Statistical Package for Social Science (SPSS 22.0) and analyzed by using Smart PLS 3.0 which is Structural Equation Modelling software. Smart PLS is able to have a reliability test on both Cronbach alpha and Composite Reliability. In addition, this software also shows the validity result including of discriminant validity and convergent validity. Furthermore, path coefficient in Smart PLS was used to test the correlation between variables. Path coefficient is an instrument to determine the relationship of hypothesized model. Besides, path coefficient can determine the most influential independent variable. Therefore, Smart PLS was in used in analyzing the whole set of data. Prior to analyze the statistical data, validity and reliability were tested to ensure data reliability and to minimize the measurement error. The reliability of the questionnaires was tested by using Composite Reliability. According to Peterson and Kim (2013), composite reliability enables the weight of the construct loadings to be different and be able to observe the data's true reliability. Meanwhile, convergent validity which is Average Variance Extracted (AVE) was tested to evaluate the data validity. Both results of the reliability and validity test were presented in Table 1 . The results show that all constructs composite reliability were ranged from 0.666 to 0.929 and they were above the recommended value of 0.50 (Fornell \& Larcker, 1981). In terms of Average Variance Extracted (AVE), it can be observed that all the constructs were above the value of 0.40. According to Fornell and Larcker (1981), Average Extracted Variance of the constructs would be acceptable if it exceeded 0.4 and the composite reliability is higher than 0.6 (Fornell \& Larcker, 1981).

\section{Table 1}

Summary of Measures

\begin{tabular}{lcc}
\hline Constructs and Indicators & Construct Reliability $(\geq 0.6)$ & Average Variance Extracted $(\geq 0.4)$ \\
\hline Consumer Involvement & & 0.621 \\
Importance & 0.830 & 0.701 \\
Pleasure & 0.875 & 0.666 \\
Sign & 0.854 & 0.548 \\
Risk Consequence & 0.666 & 0.572 \\
Risk Probability & 0.797 & 0.425 \\
Consumer Online Engagement & 0.929 & \\
\hline
\end{tabular}

\subsection{Result of the Respondents' Background}

The background of respondents was presented in Table 2. Of the sample 390,67.7\% of the respondents were female and the remaining were male. The mean age group was 36 years old is within the range of 27-37 years old representing $37.7 \%$ of the respondents. This research also found out that more than half of the respondents $(58.7 \%$ ) were Malay followed by $33.1 \%$ of Chinese and $5.9 \%$ of Indian. These findings were similar with the report presented by Department of Statistics Malaysia (2010) on the ethnic group distribution of populations in Malaysia. It indicated that Malay ethnicity is the majority ethnic group in Malaysia and followed by Chinese which is the second largest group and Indian as the third group.

Table 2

Background of Respondents ( $\mathrm{N}=390)$

\begin{tabular}{lcc}
\hline Variables & Frequency & Percentage \\
\hline Gender & & 32.30 \\
Male & 126 & 67.70 \\
Female & 264 & 29.50 \\
\hline Age & & 37.70 \\
18-26 years old & 115 & 32.80 \\
27-37 years old & 147 & 58.70 \\
38-51 years old & 128 & 33.10 \\
\hline Race & & 5.90 \\
Malay & 229 & 2.30 \\
Chinese & 129 & 23 \\
Others & 9 & \\
\hline
\end{tabular}




\subsection{Results of Hypothesis Testing}

As shown in Table 3, the path coefficient was tested on the relationship between consumer involvement and its dimensions (importance, pleasure, sign, risk consequence, and risk probability) and consumer online engagement. The findings show that consumer involvement significantly influenced consumer online engagement $(\mathrm{t}=12.749, \mathrm{p}<0.01)$. This result was consistent with the research accomplished by Vivek et al. (2009). The authors found out that consumer involvement was positively associated with the degree of engagement intensity. Involved consumers and active participants were interested in the services and caused them to engage. Liang (2012) stated that consumer product involvement has the ability to influence consumer behavior and help in developing consumer online engagement.

The result also show that importance variable was positively influencing consumer online engagement $(\mathrm{t}=4.334, \mathrm{p}<0.01)$ and consistent with the proposed hypothesis. Therefore, $\mathrm{H}_{2}$ was supported. This result has shown a similar outcome attained by Thongthip and Jaroenwanit (2016). In another study on online users' news Arapakis et al. (2014) disclosed that interested users will spend more time in browsing the social media and visits frequently. They believe this behavior will encourage engagement for the online social media content.

Similarly, this research has ascertained that pleasure variable positively influenced consumer online engagement $(\mathrm{t}=4.410, \mathrm{p}<0.01)$. Thus, hypothesis 3 was supported. Based on the findings, pleasurable consumers were more likely to stay engaged through online social media with the airline or hospitality services. This result was in agreement with Blasco-Arcas et al. (2016) where they discovered that the more intense the emotion experienced by the consumers, the larger impact on the degree of engagement. The researchers also explain that emotional feelings will give an impact to the long term relationship between consumers and the company through online environments.

The path coefficient result has portrayed a positively influences of sign on consumer online engagement $(\mathrm{t}=4.981, \mathrm{p}<0.01)$. As a result, the proposed hypothesis 4 was supported. This result indicates a significant direct relationship between sign and consumer online engagement which is in line with the findings of Choubtarash et al. (2013). The researchers discovered that sign value such as compatibility of symbolic brand of the product and personal images is important and a major indicator influencing on the purchasing decision.

The findings discovered that risk consequence was positively correlated with consumer online engagement $(\mathrm{t}=1.413, \mathrm{p}<0.1)$. In line with previous studies, the relationship between risk consequence and brand loyalty was weak yet risk consequence was positively influenced with the brand loyalty (Hochgraefe et al., 2012). However, the result was in contrast with other researches (Thongthip \& Jaroenwanit, 2016) in milk products context. The research found a significant result between risk consequence and consumer brand engagement. The dissimilar result gained by this research may because of the main focus of the research context. Product or services in different segmentations and levels of services may produce different results. In addition, the positive standard beta acquired implied that when consumers perceived importance on the possible negative consequence of a mis-purchase increase, the tendency of having online engagement also increases.

Nevertheless, risk probability does not demonstrate significant relationship with consumer online engagement. This study found a different result in comparison with the past studies with regard to private apparel brands. Interestingly, other past research (Hochgraefe et al., 2012) verified that risk probability had no significant relationship with brand loyalty. Hochgraefe et al. (2012) explained that Swiss respondents had low to medium culture of uncertainty and hence they were prone to risk taking. In this context of study, the outcome of the research revealed that risk probability insignificantly influenced consumer online engagement. A possible explanation is the respondents may have high tolerance of risk taking. Although risk probability was considered as a prudent determinant of consumer online engagement yet the result of this study show insignificant relationship. 
Table 3

Path Coefficient

\begin{tabular}{cccc}
\hline Relationship & Std Beta & t-value & Result \\
\hline IMP $>$ COE & 0.2314 & 4.334 & Significant*** \\
PLE $>$ COE & 0.2348 & 4.410 & Significant*** \\
SIG $>$ COE & 0.2444 & 4.981 & Significant*** \\
RC $>$ COE & 0.200 & 1.413 & Significant* \\
RP $>$ COE & -0.0726 & 1.037 & Not Significant \\
CI $>$ COE & 0.522 & 12.749 & Significant*** \\
\hline
\end{tabular}

Note: ${ }^{* * *} \mathrm{p}=0.01 \mathrm{t}=1.96,{ }^{* *} \mathrm{p}=0.05 \mathrm{t}=1.64,{ }^{*} \mathrm{p}=0.1 \mathrm{t}=1.28$

\section{Implications}

This research have studied an important area in the marketing context which is consumer online engagement in airline and hospitality services. This study attempts to address the potential relationships between consumer involvement and its dimensions (importance, pleasure, sign, risk consequence, and risk probability) in determining consumer online engagement. Since consumer online engagement is an emerging term in recent marketing literature there are not many studies accomplished on the relationship between consumer involvement profile dimensions with consumer online engagement specifically in airline and hospitality context. Hence, this research serves as one of the initial steps to enhance the understanding of consumer involvement and consumer online engagement.

The findings of current research were beneficial to marketing managers in term of marketing positioning. This study empirically identified that important, pleasure, sign, and risk consequence positively influenced consumer online engagement. Hence, marketers should pay more attention in creating the sense of importance to the consumers to attract their interest. In addition, marketing managers could enhance the pleasurable values to the consumers throughout their in-flight journey or services in the hotel. This can be done by providing comfortable seats, serving delicious meals, Wi-Fi services and clean environment for the consumers.

The current study also found out that sign value was an important determinant of consumer online engagement, thus examining the compatibleness of consumers' personal meaning with the symbolic values of airline and hospitality is essential. Subsequently, risk consequence plays a vital role in determining engagement of the consumers through social media. Consequently, airline and hospitality services' marketers have to minimize the risk of the consumers by ensuring the choices are correct and not disappointing. This can be overcome by portraying healthy company image and providing excellent services to increase their confidents. Marketing executives should acknowledge the importance of consumer involvement and consumer online engagement by applying this knowledge into their marketing plans.

Furthermore, this research has made significant implication for the consumers. Understanding the concept of consumer online engagement in airline and hospitality services context helps to provide a guideline for the consumers. Consumers could understand that their personal values of involvement could give an impact to their social media engagement behavior. A number of marketing strategies has been applied by the marketers to attract the attention of the consumers and eventually promote purchasing. Hence, consumers should be aware of the marketing strategies integrated by the marketers. They could apply the knowledge they possess to determine the services based on their suitability rather than attracted by those marketing strategies.

\section{Limitation and Recommendations}

Despite the implications made, several limitations do occur. This research was unable to generalize the result to the whole population of Malaysia. This is due to the sample size collected and the implementation of non-probability sampling technique. Next, the findings were unable to represent other travelers such as those who are not active social media users. Thirdly, this research only focuses on consumer involvement and its dimensions as the key determinant of consumer online engagement. Fourthly, the 
research is only focuses on airline and hospitality context and does not emphasize on any brand or company. Thus, future research can further enhance the research with minimal limitations. Future studies could further improvise the research through conducting probability sampling techniques which may be able to generalize to the whole populations. Besides, future studies could enhance the research by including the inactive social media users in cultivating consumer online engagement. Next, enhancement of other possible factors in influencing consumer online engagement is essential. Finally, future research can emphasize on other context of studies and highlight on certain brand or company.

\section{Conclusion}

Airline and hospitality services have been developed in recent years through providing transportation and a place to stay for the consumers. Many consumers are travelling more often either to overseas or to domestic locations for leisure or business trips. However, some issues such as increase of competition have caused the airline and hospitality services companies to face instability. Therefore, one of the ways to ensure competitiveness is to get engaged consumers through online social media. In this study, consumer involvement and its dimensions such as importance, pleasure, sign, risk consequence, and risk probability have been perceived as important factors in influencing consumer online engagement.

The results have also revealed consumer involvement positively influenced consumer online engagement. Different dimensions of consumer involvement may have variety degrees of influence on consumer online engagement. Among the dimensions of consumer involvement, sign value was the main influencer of consumer online engagement and has the highest $t$-value $(t=4.981)$. This has revealed that sign value in airline and hospitality services was an important determinant of consumer online engagement through social media. Sign of the airline and hospitality services company carried different symbol to represent consumer personal image and social status. Thus, marketing managers should carry out more researches regarding their current symbolic value to find out whether this is compatible with their customers' images or not. Nonetheless, this research has found out that risk probability was not correlated with consumer online engagement. A potential explanation is Malaysian make minimum prediction on mistakenly purchased product or services. Hence, consumer involvement dimensions except risk probability were prudent factors in influencing consumer online engagement through social media platforms.

\section{References}

Altschwager, T., Conduit, J., Bouzdine-Chameeva, T., \& Goodman, S. (2014, January). Customer engagement: a comparison between Australian and French wine events. In Academy of Wine Business Research, 8th Annual Conference, Hochschule Geisenheim University, Geisenheim, Germany, June (pp. 28-30).

Amiruddin, N. H. (2013). Price service quality and customer loyalty: A case of Air Asia. South East Asia Journal of Contemporary Business, Economics and Law, 2(1), 34-40.

Apenes Solem, B.A. (2016). Influences of customer participation and customer brand engagement on brand loyalty. Journal of Consumer Marketing, 33(5), 332-342.

Arapakis, I., Lalmas, M., Cambazoglu, B.B., Marcos, M., \& Jose, J.M. (2014). User engagement in online news: Under the scope of sentiment, interest, affect, and gaze. Journal of the Association for Information Science and Technology, 65(10), 1988-2005.

Blasco-Arcas, L., Hernandez-Ortega, B.I., \& Jimenez-Martinez, J. (2016). Engagement platforms: The role of emotions in fostering customer engagement and brand image in interactive media. Journal of Service Theory and Practice, 26(5), 559-589.

Brodie, R.J., Ilic, A., Juric, B., \& Hollebeek, L. (2013). Consumer engagement in virtual brand community: An exploratory analysis. Journal of Business Research, 66, 105-114.

Bowden, J. L. H. (2009). The process of customer engagement: A conceptual framework. Journal of Marketing Theory and Practice, 17(1), 63-74.

Cabiddu, F., De Carlo, M., \& Piccoli, G. (2014). Social media affordances: Enabling customer engagement. Annals of Tourism Research, 48(September), 175-192. 
Cases, A.S. (2002). Perceived risk and risk-reduction strategies in internet shopping. The International Review of Retail, Distribution and Consumer Research, 12(4), 375-394.

Celuch, K.G., Longfellow, T.A., \& Slama, M.E. (2014). Antecedents of involvement and perceived purchase risk: Better understanding the consumer involvement profile. In: Crittenden V.L. (eds) Proceedings of the 1992 Academy of Marketing Science (AMS) Annual Conference. Developments in Marketing Science: Proceedings of the Academy of Marketing Science. Springer, Cham, available at: https://link.springer.com/chapter/10.1007/978-3-319-13248-8_5

Chalil, R.D. \& Dharmmesta, B.S. (2015). The role of consumer involvement as a moderating variable: The relationship between consumer satisfaction and corporate image on service loyalty. Journal of Asian Scientific Research, 5(6), 303-319.

Chaudhuri, A. \& Holbrook, M.B. (2001). The chain of effects from brand trust and brand affect to brand performance: The role of brand loyalty. Journal of Marketing, 65(2), 81-93.

Chen, A. \& Darst, P.W. (2001). Situational interest in physical education: A function of learning task design. Research Quarterly for Exercise and Sport, 72, 150-164.

Chen, L.S., Wang, M.C., Cheng, J.M., \& Kuntjara, H. (2008). Consumer involvement and brand loyalty in services: Evidence from the commercial airline industry in Taiwan. International Journal of Services and Standards, 4(4), 437-452.

Cheung, C., Lee, M., \& Jin, X. (2011). Customer engagement in an online social platform: A conceptual model and scale development.

Choubtarash, N., Mahdieh, O., \& Marnani, A.B. (2013). The study of the relationship between consumer involvement and purchase decision (Case study: Cell phone). Interdisciplinary Journal of Contemporary Research in Business, 4(12), 276-296.

Department of Statistics Malaysia (2011), Population distribution and basic demographic characteristics report 2010. Retrieved at: https://www.dosm.gov.my/v1/index.php? $r=$ column/cthemeByCat\&cat $=117 \&$ bul id=MDMxdHZjWTk1SjFzTzNkRXYzcVZjdz09\&menu id=L0pheU43NWJwR WVSZk1WdzQ4TlhUUT09\#

Dessart, L., Veloutsou, C., \& Morgan-Thomas, A. (2015). Consumer engagement in online brand communities: a social media perspective. Journal of Product \& Brand Management, 24(1), 28-42.

Donovan, A.W. (2005). Yield management in the airline industry. Journal of Aviation/ Aerospace Education \& Research, 14(3), 11-19.

Dovaliene, A., Piligrimiene, Z., \& Masiulyte, A. (2016). Factors influencing customer engagement in mobile applications. Engineering Economics, 27(2), 205-212.

Farook, F.S. \& Abeysekara, N. (2016). Influence of social media marketing on customer engagement. International Journal of Business Management Invention, 5(12), 115-125.

Fernandes, T. \& Esteves, F. (2016). Customer engagement and loyalty: A comparative study between service contexts. Service Marketing Quarterly, 37(2), 125-139.

Firat, A., Kutucuoglu, K.Y., Saltik, I.A., \& Tuncel, O. (2013). Consumption, consumer culture and consumer society. Journal of Community Positive Practices, 13(1), 182-203.

Floreddu, P.B \& Cabiddu, F. (2016). Social media communication strategies. Journal of Services Marketing, 30(5), 490-503.

Fornell, C. \& Larcker, D.F. (1981). Evaluating structural equation models with unobservable variables and measurement error. Journal of Marketing Research, 18(1), 39-50.

Gerber, C., Ward, S., \& Goedhals-Gerber, L. (2014). The impact of perceived risk on on-line purchase behaviour. Risk Governance of Control: Financial Markets \& Institutions, 4(4), 99-106.

Greve, G. (2014). The moderating effect of customer engagement on the brand image-brand loyalty relationship. Procedia-Social and Behavioral Sciences, 148, 203-210.

Guha, S., Harrigan, P., \& Soutar, G. (2018). Linking social media to customer relationship management (CRM): A qualitative study on SMEs. Journal of Small Business \& Entrepreneurship, 30(3), 193-214.

Guthrie, M.F. \& Kim, H. (2009). The relationship between consumer involvement and brand perceptions of female cosmetic consumers. Journal of Brand Management, 17(2), 114- 133.

Harrigan, P., Evers, U., Miles, M., \& Daly, T. (2017). Customer engagement with tourism social media brands. Tourism Management, 59, 597-609. 
Harwood, T. \& Garry, T. (2015). An investigation into gamification as a customer engagement experience environment. Journal of Services Marketing, 29 (6/7), 533-546.

Hochgraefe, C., Faulk, S., \& Vieregge, M. (2012). Links between Swiss hotel guests' product involvement and brand loyalty. Journal of Hospitality Marketing \& Management, 21(1), 20-39.

Hollebeek, L. D., Glynn, M. S., \& Brodie, R. J. (2014). Consumer brand engagement in social media: Conceptualization, scale development and validation. Journal of interactive marketing, 28(2), 149165.

$\mathrm{Hu}, \mathrm{Y}$. (2012). Explore significant factors to affect customer involvement. Journal of Social Sciences, $8(4), 485-489$.

IATA Economics. (2018). Airlines financial monitor. Retrieved from: https://www.iata.org/publications/economics/Reports/afm/Airlines-Financial-Monitor-Ap r-18.pdf

Internet World Stats (2017), Usage and population statistics. Retrieved at: http://www.internetworldstats.com/asia.htm\#my

Ion, D.C. (2011). Impact of globalization on airport industry. Paper presented at International Conference of Scientific Paper AFASES 2011, 26-28 May 2011, Germany, available at: http://www.afahc.ro/ro/afases/2011/manag/Ion.pdf

Kapiki, S. (2012). Current and future trends in tourism and hospitality: The case of Greece. International Journal of Economic Practices and Theories, 2(1), 1-12.

Kapferer, J. N., \& Laurent, G. (1985). Consumer involvement profiles: a new and practical approach to consumer involvement (No. hal-00786782).

Wirtz, J., Ambtman, A., Bloemer, J., Horvath, C., Rameseshan, B., Klundert, J., Canli, Z.G., \& Kandampully, J, (2013). Managing brands and customer engagement in online brand communities.Journal of Service Management, 24(3), 223-244.

Jung, S., \& Jin, B. (2016). Sustainable development of slow fashion business: Customer value approach. Sustainability, 8(6), 540.

Kim, H. (2005). Consumer profiles of apparel product involvement and values. Journal of Fashion Marketing and Management: An International Journal, 9(2), 207-220.

Leckie, C., Nyadzayo, M. W., \& Johnson, L. W. (2016). Antecedents of consumer brand engagement and brand loyalty. Journal of Marketing Management, 32(5-6), 558-578.

Lee, S., Workman, J.E., \& Jung, K. (2016). Brand relationships and risk: Influence of risk avoidance and gender on brand consumption. Journal of Open Innovation: Technology, Market, and Complexity, 2(4). Retrieved from: https://link.springer.com/content/pdf/10.1186\%2Fs40852-016-0041-0.pdf

Lerrthaitrakul, W. \& Panjakajornsak, V. (2014). The airline service quality affecting post purchase behavioral intention: Empirical evidence from the low cost airline industry. International Journal of Trade, Economics and Finance, 5(2), 155-158.

Li, X. \& Sun, C. (2015). A study on the core values of the brand. Journal of Services Science and Management, 8, 868-873.

Liang, Y. (2012). The relationship between consumer product involvement, product knowledge and impulsive buying behaviour. Procedia Social and Behavioral Sciences, 57, 325-330.

Lowrance, W.W. (1976). Of acceptable risk: Science and the determination of safety. Los Altos: US.

Masoud, E.Y. (2013). The effect of perceived risk on online shopping in Jordon. European Journal of Business and Management, 5(6), 76-87.

Mukherjee, A. \& Nath, O. (2007). Role of electronic trust in online retailing: A re-examination of the commitment-trust theory. European Journal of Marketing, 4(9/10), 1173-1202.

Nasution, H.N. \& Mavondo, F.T. (2005). The impact of service quality on customer value in the hotel industry. Paper presented at: ANZMAC Conference: Tourism Marketing. Retrieved from: http://anzmac.org/conference_archive/2005/cd-site/pdfs/19-Tourism/19-Nasution.pdf

O'cass, A., \& Fenech, T. (2003). Web retailing adoption: exploring the nature of internet users Web retailing behaviour. Journal of Retailing and Consumer services, 10(2), 81-94.

Ohajionu, U.C. \& Mathews, S. (2015). Advertising on social media and benefits to brands. Journal of Social Sciences and Humanities, 10(2), 335-351. 
Ong, W.L., \& Tan, A.K.G. (2010). A note on the determinants of airline choice: The case of Air Asia and Malaysia airlines. Journal of Air Transport Management, 16, 209-212.

Oyewole, P., Sankaran, M., \& Choudhury, P. (2008). Consumer choice of airlines in Malaysia: A Synthesis of perspectives from participants in the air travel market. Journal of International Consumer Marketing, 20(1), 19-31.

Parker, C.J. \& Wang, H. (2016). Examining hedonic and utilitarian motivations for m-commerce fashion retail app engagement. Journal of Fashion Marketing and Management: An International Journal, 20(4), 487-506.

Peterson, R. A., \& Kim, Y. (2013). On the relationship between coefficient alpha and composite reliability. Journal of Applied Psychology, 98(1), 194.

Quester, P., \& Lin Lim, A. (2003). Product involvement/brand loyalty: is there a link?. Journal of Product \& Brand Management, 12(1), 22-38.

Rahbarian, H., \& Meshkani, F. (2014). Consumer involvement profiles: An application of consumer involvement in mobile industry. Management Science Letters, 4(4), 617-620.

Roux, I.I. \& Maree, T. (2016). Motivation, engagement, attitudes and buying intent of female Facebook users. Acta Commercii-Independent Research Journal in the Management Sciences, 16(1). Retrieved from: http://dx.doi.org/10.4102/ac.v16i1.340

Sawyer, R. (2011). The impact of new social media on intercultural adaptation. Senior Honors Projects, 242. Retrieved at: http://digitalcommons.uri.edu/cgi/viewcontent.cgi?article=1 230\&context=srhonorsprog

Smith, J. (2004). Do airport hotels continue to be a growth opportunity, and which airports present the best opportunities. Journal of Retail \& Leisure Property, 4(1), 9-17.

So, K.K.F., King, C., Sparks, B.A., \& Wang, Y. (2016). The role of customer engagement in building consumer loyalty to tourism brands. Journal of Travel Research, 55(1), 64-78.

Sukati, I., Khiang, T.B., \& Isnurhadi. (2015). Customer satisfaction level provided by Air $\quad$ Asia. Asian Social Science, 11 (13), 16-27.

Statista (2018). Number of social network users worldwide from 2010 to 2021 (in billions). Retrieved from: https://www.statista.com/statistics/278414/number-of-worldwide-social- network-users/

Statista (2018a). Social Media Statistics \& Facts. Retrieved from: https://www.statista.com/topics/1164/social-networks/

Syaqirah, N.Z. \& Faizurrahman, P.Z. (2014). Managing customer retention of hotel industry in Malaysia. Procedia- Social and Behavioral Sciences, 130, 379-389.

The Statistical Portal, (2017 April), Revenue of commercial airline worldwide from 2003 to 2017 (in US dollar), retrieved from: https://www.statista.com/statistics/278372/revenue-of-commercial-airlinesworldwide/

Thongthip, W. \& Jaroenwanit, P. (2016). The influence of product involvement and perceived value on customer brand engagement of Thai and Lao consumer: A case of milk products. Paper presented at the Proceedings of 53rd ISERD International Conference Zurich, Switzerland, 30th-31st October 2016.

Truong, Y. (2010). Personal aspirations and the consumption of luxury goods. International Journal of Market Research, 52(5), 653-671.

Turner, R. (2018). Travel \& tourism economic impact 2018 world. London, UK. Retrieved from: https://www.wttc.org/-/media/files/reports/economic-impact-research/regions-2018/world2018.pdf

Turner, R. (2018a). Travel \& Tourism economic impact 2018 Malaysia. London, UK. Retrieved from:https://www.wttc.org/-/media/files/reports/economic-impact-research/countries2018/malaysia2018.pdf

Van Doorn, J., Lemon, K. N., Mittal, V., Nass, S., Pick, D., Pirner, P., \& Verhoef, P. C. (2010). Customer engagement behavior: theoretical foundations and research directions. Journal of service research, 13(3), 253-266.

Vazifehdoost, H. \& Kia, A. (2015). Investigation of the influence of purchase involvement dimensions on brand loyalty. Journal of Applied Environmental and Biological Sciences, 5(5), 420-427. 
Vivek, S. D., Beatty, S. E., \& Morgan, R. M. (2012). Customer engagement: Exploring customer relationships beyond purchase. Journal of Marketing Theory and Practice, 20(2), 122-146.

Kunz, W., Aksoy, L., Bart, Y., Heinonen, K., Kabadayi, S., Ordenes, F.V., Sigala, M., Diaz, D., \& Theodoulidis, B, (2017). Customer engagement in a big data world. Journal of Services Marketing, 31(2), 161-171.

Wirtz, B.W. \& Gottel, V. (2016). Technology acceptance in social media: Review, synthesis and directions for future empirical research. Journal of Electronic Commerce Research, $\quad$ 17(2), $97-$ 115.

Zhang, S., Jiang, H., \& Carroll, J.M. (2011). Integrating online and offline community through Facebook. Paper presented at the 2011 International Conference on Collaboration Technologies and Systems, 569-578. Piscataway, NJ: IEE Press.

Żyminkowska, K., Żyminkowski, T., \& Błaszczyk, R. (2017). Effects of customer engagement behaviour. Journal of Economics and Management, 28(2), 133-154.

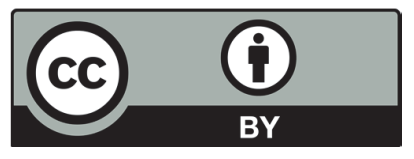

(C) 2019 by the authors; licensee Growing Science, Canada. This is an open access article distributed under the terms and conditions of the Creative Commons Attribution (CCBY) license (http://creativecommons.org/licenses/by/4.0/). 